\title{
The Report of the Non-Ferrous Mining Committee
}

DRING the last few months we have frequently referred in our Editorial Notes to the proceedings of the Board of Trade Committee on the Non-ferrous Mining Industry. This committeewhich was composed as follows: Mr. H. B. Betterton, M.P. (chairman), Mr. H. F. Collins, Mr. J. Harris, Dr. F. H. Hatch, Mr. R. A. Thomas, Mr. J. Wignall, M.P., and Sir Lionel Phillips, who was obliged to resign very soon after appointment - has now with commendable promptitude issued its report, a document of much interest from many points of view. While not primarily concerned with the geological aspects of British non-ferrous mining, the Committee have nevertheless investigated with some thoroughness certain geological matters in connexion with the tin lodes of Cornwall, the lead-zinc deposits of northern England, Scotland, and Wales, and the barytes of Shropshire. A most interesting extract is given from a report by Dr. Malcolm Maclaren to Messrs. Bewick, Moreing and $\mathrm{C} o$., on the central mines of the Camborne-Redruth area, summarizing his views on the limits in depth of profitable tin working in that district. Dr. Maclaren points out that in most instances there is a marked falling of in tin-content at an average depth below the granite-killas contact of about 200 fathoms, or some 360 fathoms from the surface; only in one case, the well-known Dolcoath ore-body, did productive ore extend much below this; even this has failed at about the 500 fathom level. The facts here summarized are entirely consistent with the views as to the existence of definite mineral zones brought forward in the recent paper by Dr. W. R. Jones at the Institution of Mining and Metallurgy, and in the discussion on that paper by Professor Cullis, Mr. Rastall, Dr. Hatch, and other speakers. Favourable reference is also made to the projects for exploration below the abandoned shallow mines of this district by means of cross-cuts driven from the workings of the larger and deeper mines. It is certain that the granite-killas contact must extend far to the north of its surface outcrop at no very great depth; there is every probability that this contact is in point of fact an undulating one, and account must be taken of the fact that granite again comes to the surface at St. Agnes, where also there is well-developed mineralization. It seems probable that all the granite bosses of Cornwall and Devon are in point of fact local domes, cupolas in the American sense of the term, on the surface of a great bathylith, underlying the whole region at a rather small depth. It is of course uncertain what this actual depth may be, and in places it is probably below the limit of working under present conditions; there is also the further fact to be taken into account that in America it is believer that ore-minerals tend to concentrate themselves in the upper parts of these cupolas. Hence it is not safe to infer the existence of a tin-zone all over the upper surface of the 
bathylith. Nevertheless the widespread occurrence in the shallower mines of copper lodes is an encouraging feature from this point of view, suggesting the existence below them of the tin, wolfram, and arsenic zones. Several witnesses before the Committee asked for financial assistance from the Government to assist explorations of hitherto undeveloped deep-level areas, and it may be said that geological theory, so far as it goes, is favourable to the prospects of a successful issue.

Considerable space is devoted to a description of the projects for the drainage to lower levels of the Halkyn-Llanarmon area in Flintshire, which is considered to be perhaps the most important area of lead and zinc ores in the whole country. Here the problem is mainly geological, and depends wholly on the well-known watercarrying capacity of the Carboniferous Limestone and the consequent peculiar behaviour of the river system of that district. Here the geology is perfectly simple, and the whole question is now mainly financial; if the project for the continuance of a new sea-level drainage tunnel (which has been alreadystarted) can be carried out, some extraordinarily rich and productive veins can be worked down to a much lower level than at present, and a large addition made to the home supply of lead and zine for many years to come. This seems to be pre-eminently a case for Government assistance. The case for a similar scheme for the Wanlockhead and Leadhills district appears to be less convincing, and neither the companies concerned nor the royalty owners seem to display much enthusiasm on the subject, owing to the immense capital expenditure necessary for a 7 mile tunnel in hard Palæozoic rocks.

Another point of geological interest arises in connexion with the lead-zine deposits of Northumberland, Durham, and adjoining counties, which are chiefly in the Great Limestone, and are approaching exhaustion. Professor Louis suggested in evidence before the Committee that trial should be made of the Melmerby Scar Limestone as another possible productive horizon. This raises an interesting question as to the influence of the Whin Sill on oredeposition in this neighbourhood, as to which little information seems to be available. It is generally stated that in Derbyshire lead-zinc ore-bodies are not found in payable quantities below the toadstone, a presumably impervious igneous rock; this suggests a downward movement of the mineralizing solutions. On the other hand, according to accepted modern theories of ore-deposition, the movement should be upward and the ores found below the igneous rock. To one unacquainted with local conditions the question at once suggests itself whether proper explorations have ever been carried out below the toadstone, or whether the absence of ore there is an assumption. With regard to the Whin Sill and the northern area the same question is pertinent; as is well known, the Whin Sill is transgressive, occurring at different horizons in the Carboniferous at different places, and it may be suggeated that 
explorations should be carried out specially in localities where the sill is either immediately above or immediately below an important limestone, with a view to testing the validity of the two lines of contradictory argument as above set forth.

With regard to practical and administrative matters the Committee have dealt with many points, such as mineral leases, wayleaves, easements, the incidence of taxation, royalties, wages, State aid, and mine regulations in general. This is not the place to discuss any of these in detail, but it is permissible to say a few words as to what is in some ways the most important recommendation of the Committee, namely the constitution on a permanent footing of a Mines Department; it is suggested that the existing Mineral Resources Development Branch of the Board of Trade should be expanded and furnished with a suitable technical staff, including mining engineers and mining geologists, with a view to its ultimately forming a sub-department for metalliferous mining of a new Mines Department under the control of a minister. This is a most important recommendation, and it is highly desirable that it should be carried out at once. We have already more than once drawn attention to the existing overlapping of duties, waste of time and expense that will arise from the present multiplicity of authorities controlling the mining industry of the British Isles, and we look forward with confidence to the time when all of these will be centralized and co-ordinated into one organization adapted to the needs and potentialities of this great industry. 